\title{
THE ACOUSTICAL EFFECT OF THE HEAD AND THE EXTERNAL AUDITORY CANAL ON HEARING ACUITY
}

\author{
By
}

\author{
H. IKEDA
}

\begin{abstract}
From the Department of Oto-Rhino-Laryngology, Tokyo Medical and Dental University.
(Director: Prof. S. Horiguchi Prof. Y. Onchi)
\end{abstract}

The acoutical effect is meaured by subjective as well as objective method. In the former, the minimal audible thresholds of the subjects are meaured respectively by controlling the intensities of various pure tone sources, while they are turned around the subjects from front to side. In the latter, the variation of the sound pressure in the entrance of the external auditory canal are measured by a probe tube microphone for various frequencies. The both results coincide well each other. In addition, the frequency characteristic of the external auditory canal is analyzed by measuring the ratio of sound pressure on the tympanic membrane to the sound pressure at the entrance of the external auditory canal and the ratio of sound pressure in the entrance of the external auditory canal to the sound pressure in the free-field.

A new method of measurement of hearing acuity can be found from the results of the above mentioned experiments and it is also proved by additional several acoustical measurements to be more reasonable than any other method has been used.

\section{頭部及び外耳道の聴力に及ぼす作用の研究}

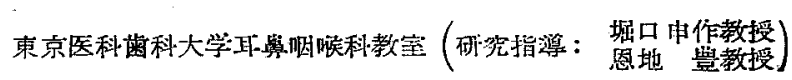<smiles>[14CH]#C[As]</smiles>

\section{目次}

I 䋨 言

II 実験材䉺とその澌定裝置

i 実験材糊

ii 測定裝置

III頭部の聴力に及ぼす影醔

N 外工道入口部の吾姮特性

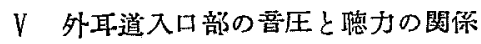

V] 外耳道の音響特性

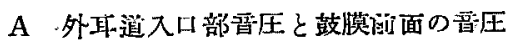

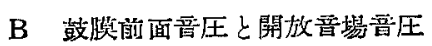

VII 外正道入口部と同じ曋圧を受話澎にて発生ざしめ た紫合の䏇方

VII 総括

X 結 語

\section{I. 緒 言}

耳外外来の物理的変化 (音波)に反応寸る感覚器官て ある以上，物里的法則に従らであるうと考えられる・故 に聴覚現象を外部的な条件より研究をした・聴力䗝查で は耳に受話器をあて〉聴力を測定するが，これはこの条 件下において得られる德力の测定值である. 同じ耳でる 条件が違えば，この测定值は変化すると考えられる。聴 力は日常開放された空間に和ける音波を受ける条件にお ける聴力であるが「オージオメトリー」では受話器を耳 にあてた不自然な条件に特ける聴力であるから，而㨋の 間に乱ける㯖力に相異のあるのは当然である.この関保 について正砝詳細な研究は少い. 空中の音波は直進する が，物体に当つた場合一部は反射され，他は物体の表面 に沿つて迴折する性質があるから，音波が頭部に当つた 埸合にもこの現象は起る・波長が大なる場合には廹折が 
藷明となり，音波の波長が短くなり頭部の直径に近ずく につれて，䫏部の 前面には反射を生じ，その背後には 幾何学的湑を生ずる. その理論は, Rayleigh, Lamb, Morse 及び Muller 等によつて述べられている. Muller, Black 及び Dunn の球体炕よる音波の迴折は第 1 图の如くであり

第1図 Muller等の球体による晋波の䞮折に 就ての実䮖值

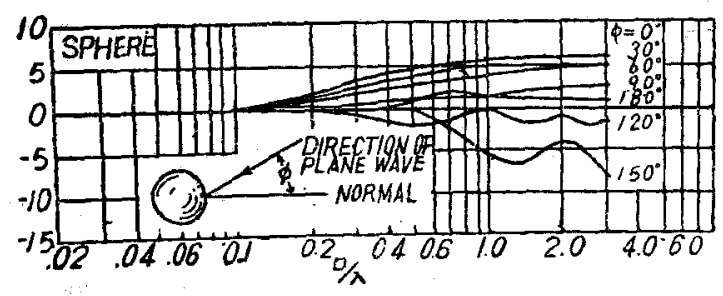

Journal of acoustical Society of America, July 1938.

音源が頍部前面にある埸台，碩部前面は波長が短くな るにつれて，球の直徍が波長の0.6 以上になつた時は， 球の前面音仕は $5 \mathrm{db}$ 乃至 $6 \mathrm{db}$ に達与る. 球の後面（音 源に対して $150^{\circ}$ ) の所は音圧が逆に $5 \mathrm{db}$ 程度低下゙する ようになつている事が㒛められる。

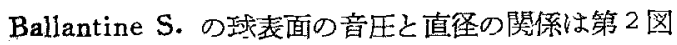
の如くで

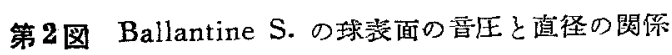

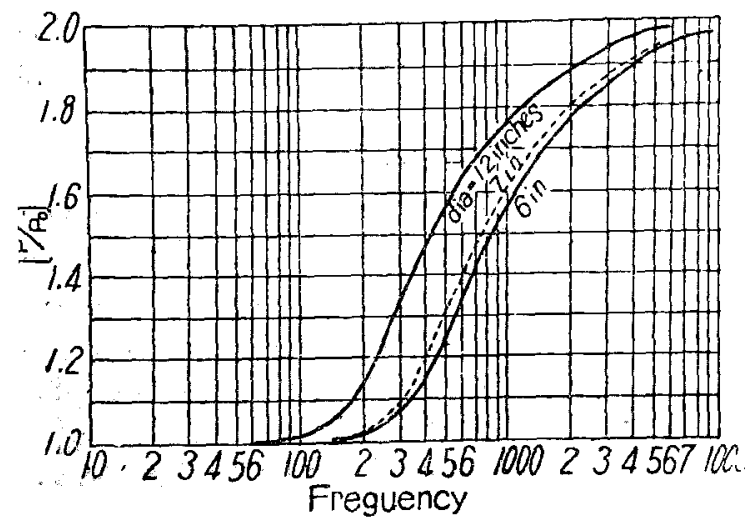

Physical Review Dec 1928.

直佳6 时の球体面上の音代は，12 时の球体面上の音 仕より高くなつている.かつ両者に括いても音波の周波 数加增大するにつれて, 球体面上の音圧（音源方向）は 曾加し，1000 cps では 6 时の球体は自由音場の音圧より 的 1.6 倍即ち $4 \mathrm{db}$ になつて拈り，4000cps 亦は $5000 \mathrm{cps}$
になると，両球体共に 2 倍即ち $6 \mathrm{db}$ に達している・こ の現像を人体頭部について，物理的に測定した研究は Winner and D.A. Ross と山ロのがある.

第3 図 Winner and D.A. Ross による栓塞外 耳道口と音場の曋圧比

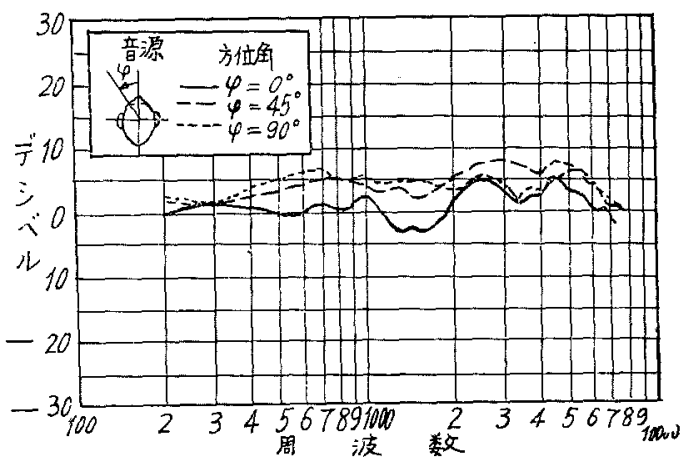

Journal of Acoustical Society of America Oct 1946.

第 3 図は Winner and D.A. Ross の測定值で音場音 在と，外耳道を閉塞した場合の外耳道入口の音王との比 である。

これと同栐な山口の测定は第4図である、雨者共に頭 部及び耳敫が外耳道に及法す音響特性に相当するが，而 者の間には，かなりの著しい差がある・自由音場に甜け る頭部の音波の迴折及び反射現象によつて以上の如く頭

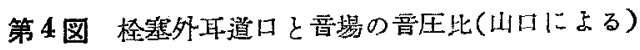

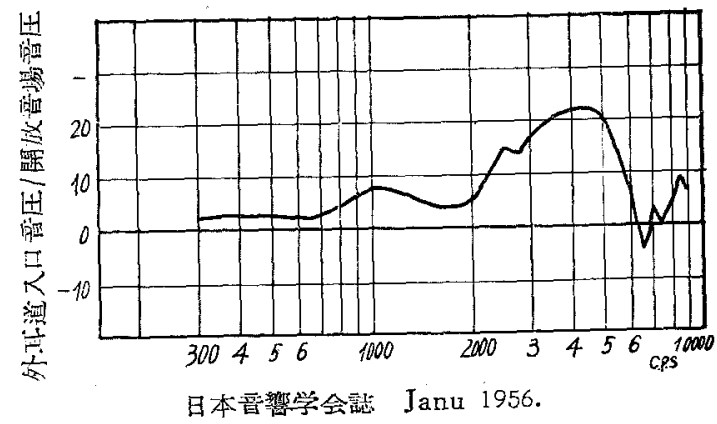

部の異なる部位の表面には，音仕の相異が生ずる故に音 源の方向によつて，同一音压でも聴力に相巽をきたす。 この関保を測定したものに Tröger, Sivian and White 及び Steinberg がある。

第 5 図は Tröger の測定で，音の大きさ10phone の 音源を一定の距離より種々なる方向から純音をあたえた 場合の右耳の感度の变化が示めされている・その中央は 
第 5 図 晋源の方向と右耳聴力の瓷化 (Trögerによる)

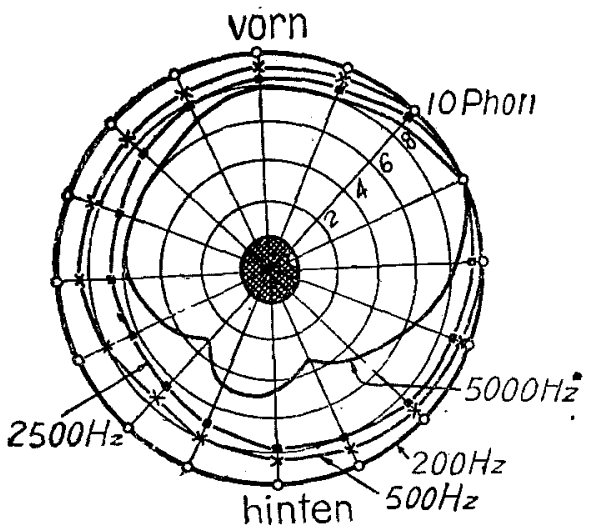

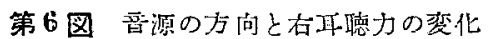
(Sivian and White による)
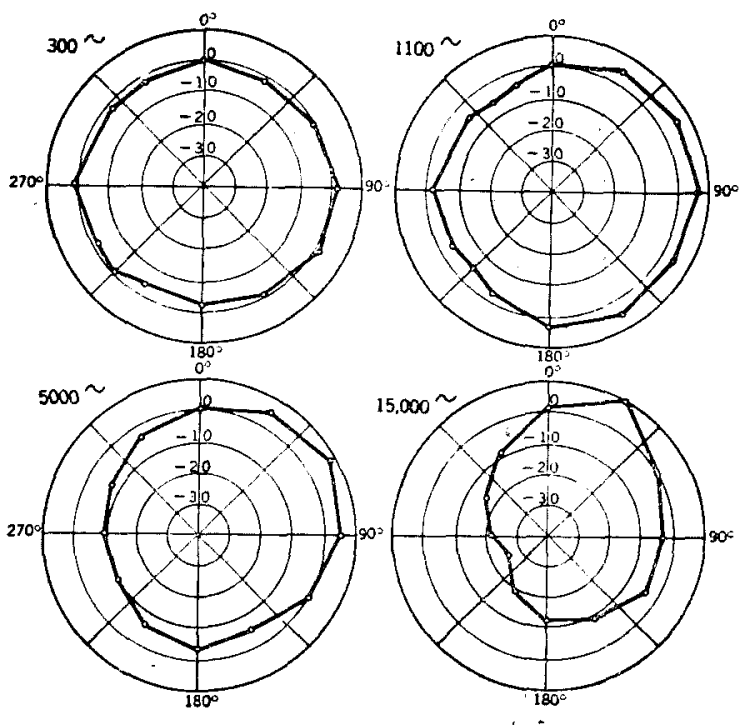

頭部である・京心円は音の大きさを表わしている・

第6図は Sivian and White の測定成績で円周上索 移動する純亯音源に嚆する在耳聴力の変化であり音源が 前面正中にある埸合の右耳の閔值に相当する音源の強さ を0dbであらわし 300cps $1100 \mathrm{cps} 5000 \mathrm{cps}$ 及び 15000 cpsについて测定を行つている. Steinberg の测定は 第7图で純音高発している音源が被䖽者の右から左に移 動した埸合の被検者の右汎㕲ける音の大きさの变化を Deribel で各周波擞について図示している。
7 図

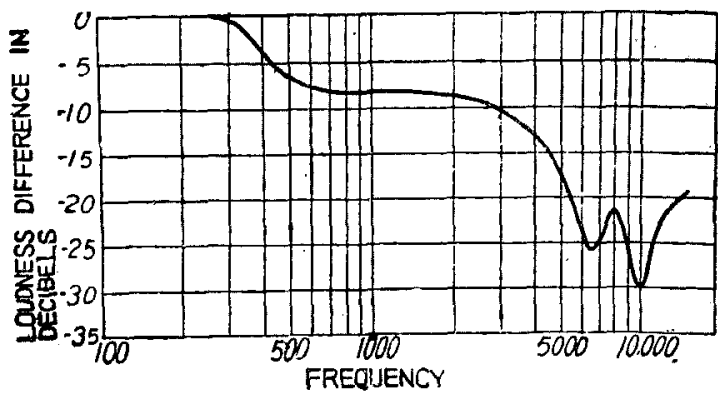

音源が右真横にある場命の音の大きさを $0 \mathrm{db} と し て ，$ これを規蕉とし，音源を左側に移動させた場合の音の大 きさを比較している。

（詰 20phone と 10phone の差は 10db と記载す ペきて 10phone ではない)

第 5 图及び第7 図共に 500cps か.ら頭部の耳に対す る影響が現れている・この再図においては頋部の影㸷 のほかに，耳殼及び外耳道の意響特性もふくまれて剆 定された結果である。

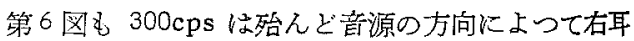
に聴取される音の大ささは变化はないが500epsの湘 定恬なく $1100 \mathrm{cps}$ では変化が現れている. 周波数が 増加するにつれてますます音源の方向による右耳に 聴取される音の強さは変化している．15000cpsでは 右 $30^{\circ}$ の方向で最多純音が強く聴取されている。これ は恐らく高周波活ど作用が著明となる右耳殼の集音作 用によると考えられる。

外耳道の音篦特性は外耳道が音波にくらべて比較的 短いからその固有振動は哃く，Rinne はf4 すなわら (2733)を Helmholtzは C4は (2048) Hansen は d4 (2298) 妓び a4（3444）上考光られている。 Bekesy は頭部と外耳道の差晎によって 227，前面に あた党られる音代の最大「ピーク」を $2400 \mathrm{cps} と し$ ている・

第8図は Winner and D.A. Ross の測定値である。 Winner and D.A. Ross の测定值は，もつとも正磪 と思われるが，垈研究者によつて外耳道の共鳴は色々に 想像されていたが，この両者によつて始めて正確になつ た。

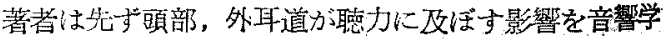

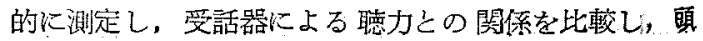
部，外耳道の音響特性を测定し得たので報告する。 
第 8 图，外耳道周波数特性（Winner and D.A Ross 被検耳 12 耳の本均俻)

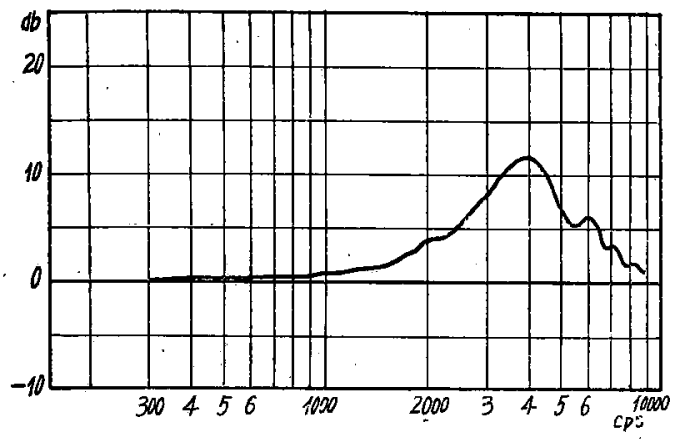

II. 実験材料とその測定装置

i) 実験材料

被検者は既往歴, 鼓膜所見, 純音聴力検, .查耳栓骨導

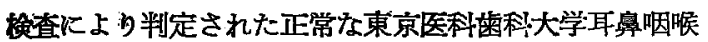
科教堂の医局員及び学生を用いた。

ii) 測定装置

測定装置は第9図に示めされたブロックダイヤグラム で，第 10 図はその一部の写真で Probe tube 用音王更 正装置であり, 発振器, 減衰抵抗器, 電任計, Probe tube microphone, Speaker よりなり, 発振器よりの

第9図 測定䔖置のブロックダイャグラム

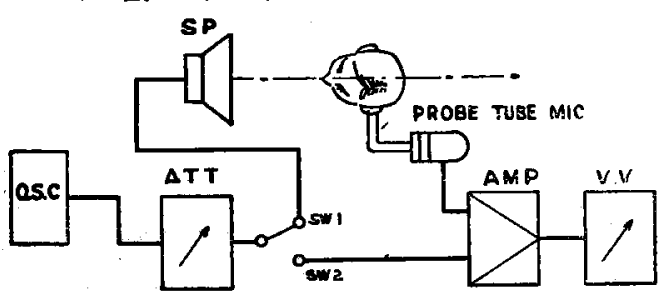

第 10 図 probe tube 用音圧更正溶置

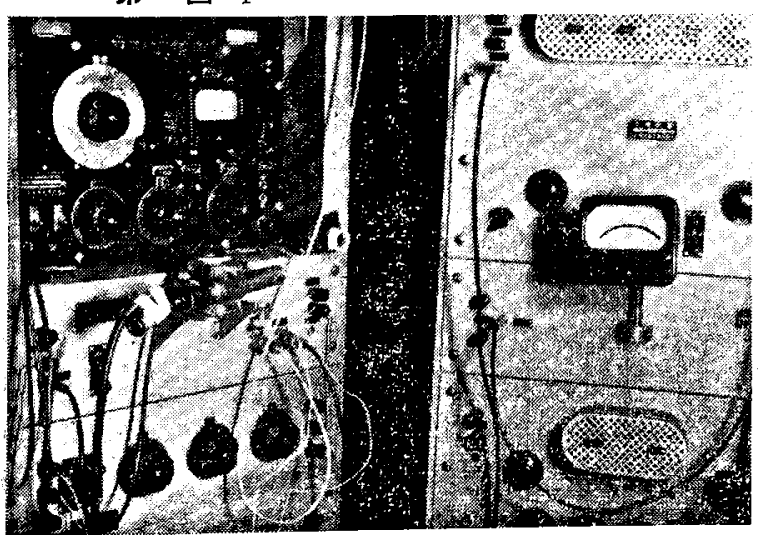

出力は，減壹抵抗器を通り，切窦え「スイッチ」SWI にて speaker より発音される. 発振器の同出力は同減 衰抵抗器を通り「スィッチ」SW2 とよつて，増幅器に 接続され Probe tube microphone かららの出力とが， 電生計によつて比較更正した. Speaker の出力はこれ によつて絶体音王にて測定された。

\section{III. 頭部の聴力に及ぼす影響}

i) 测定方法

第9図の純音発振器に接続した Speaker より $50 \mathrm{~cm}$ の距離に Probe tube microphone の先端を置き，発 振器の音圧が 60db になつた事を Probe tube microphone にて測定した後に, Probe tube microphone 除き，その位置に被検者の片方の耳の外耳道入口を置 き，他耳は耳柽をして，音源の強さを $60 \mathrm{db}$ より $1 \mathrm{db}$ 減衰抵抗器にて音圧を減少させ，最少可聴間值に達せ乙 める。このよ5にして得られる $60 \mathrm{db}$ level より最少可 聴間值にいたるむでの減衰抵抗值を各周波数について， 2つの条件に执いて測定した。

この 2 条件は，音源の方向が，正面にある場合と，側 面にある場合とであり，非検側の耳は耳栓した.

ii) 湘定綕果

被覦者10名より得られた代表的な湘定は第 11 図 1 , 2, 3, 4 である.

60db level を 0 level として，それより音圧を低下させ て閩值に達する迄の抵抗值を縰軸に取り，一db で現わ し，横軸に周波数を取る事によって表示すれば第 10 図 の特性曲線が得られる。

実線は音源が正面にある時の測定值で，割線は音源が 側面炕ある場合の特性曲線である.0 level より上方に ある曲線汪ぞ感度が良好である。4例のそれぞれの測定 曲線を通じて音源が側面にある場合は，前面にある場合

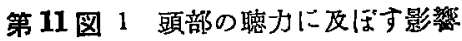
実線代晋源正面 彗線仁音源側面の埸合

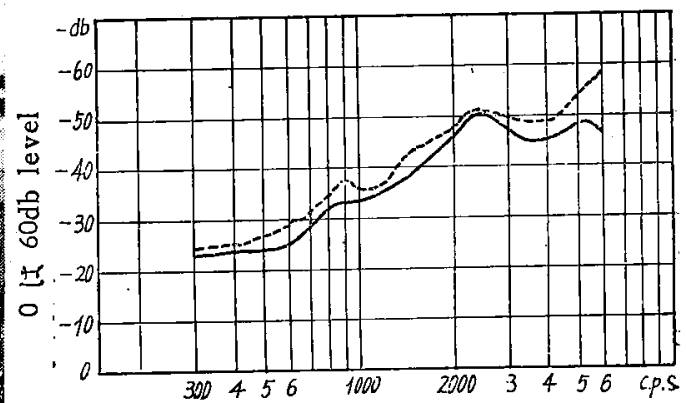


第11 图 2、頭部の聴力に及にす影䚀 実線は音源正面 制線は曋源側面の埸合

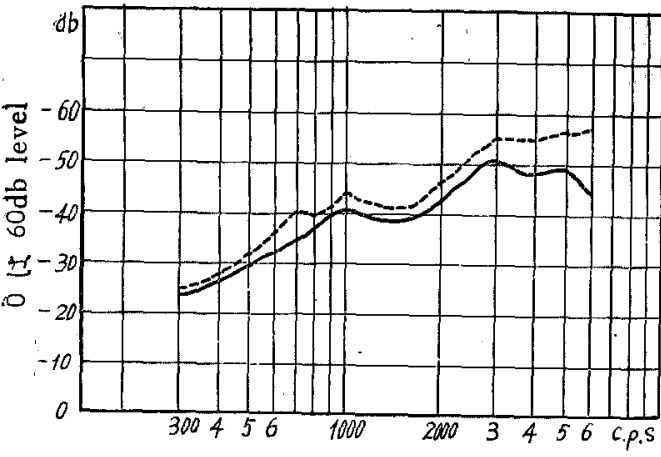

第 11 図 3 頭部の聴力に友ばす影繁

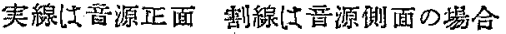

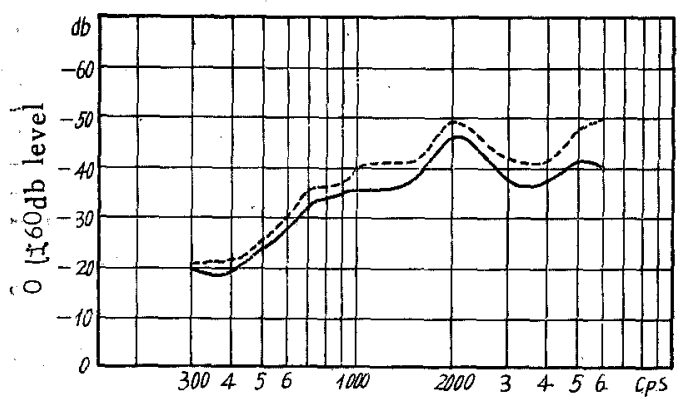

第11図 4 碩部の㯖力に及ぼす影珤

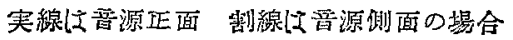

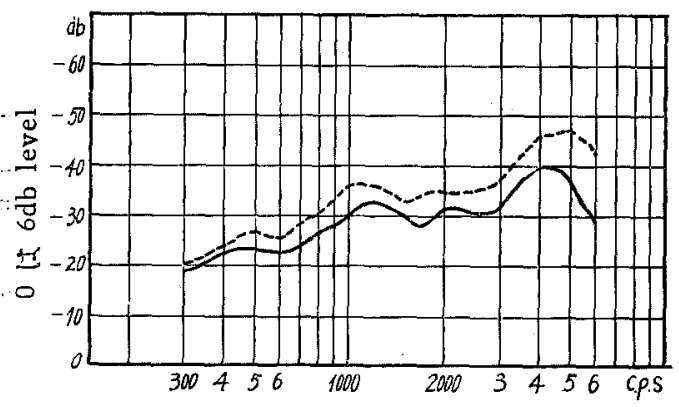

第 11 図 5 被湌者 10 名の個人差

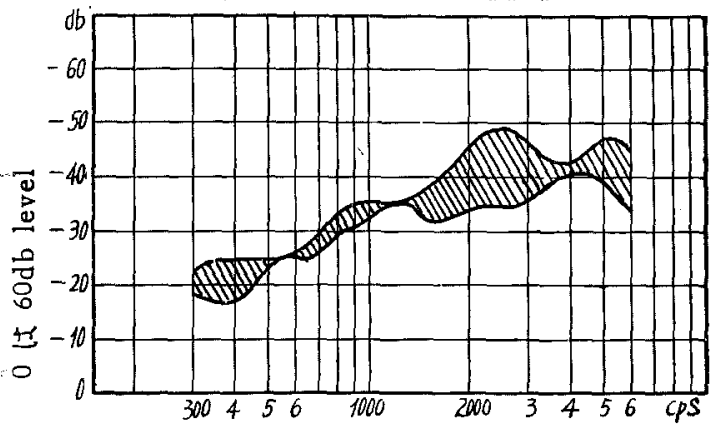

よりる聴力は良好である・しかし $300 \mathrm{cps}$ 上下は音源の 方向によつて聴力は殆んど差はないが高音になるにつれ て，音源側面の聴力が増加している。

頭部の 影響は個人によつてその相異があり，300cps では 0 乃至 $2 \mathrm{db}, 500 \mathrm{cps}$ では 2 乃至 $3 \mathrm{db}, 1000 \mathrm{cps}$ で は 2 乃至 $6 \mathrm{db}, 2000 \mathrm{cps}$ では 1 万至 $3 \mathrm{db}, 3000 \mathrm{cps}$ では 3 不至 $5 \mathrm{db}$, $4000 \mathrm{cps}$ では 4 乃至 $6 \mathrm{db}, 5000 \mathrm{cps}$ では? 乃至 $10 \mathrm{db}, 6000 \mathrm{cps}$ では 10 妊至 $14 \mathrm{db}$ であり，個人 差は非常に少ない。

\section{IV. 外耳道入口部の音響特性}

i) 测定方法

前記第 9 図の装置を用いて音源より $50 \mathrm{~cm}$ の位置に 幁部を置き，外耳道入口部の音纴を Probs tube microphone にて测定し，㳄いで probe tube microphone はその位直に固定したま〉，被検者のみ去らしめて 開放音場音仕を各周波数について湘定する。この両者の 音珐比を各周波数について求めた・なお測定には，音源 の方向が正面にある埸合上，側面にある場合の 2 条件に ついて測定した。その結果が第12図である・

ii）测定緒果

被検者 10 名より得られた代表的な測定は，第 12 図 a, b である. 奏線は音源が正面にある時の測定值で,

第 12 図 a 外耳道入口部の害鹤特性 実線行吾源正面 割線仕音源側西の場合

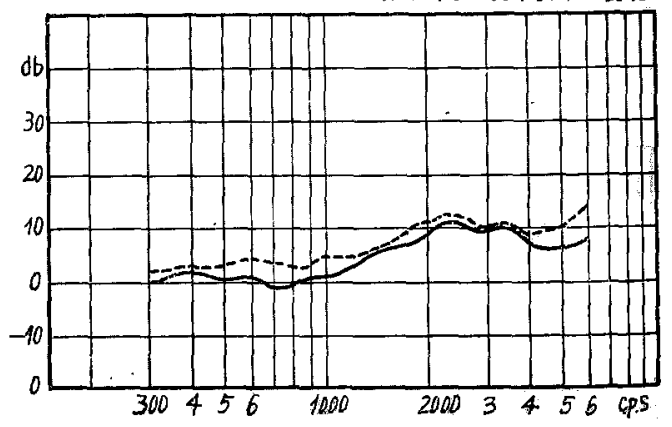

第 12 図 b 外耳道入口部の美暗特性

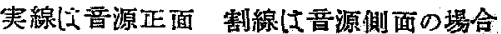

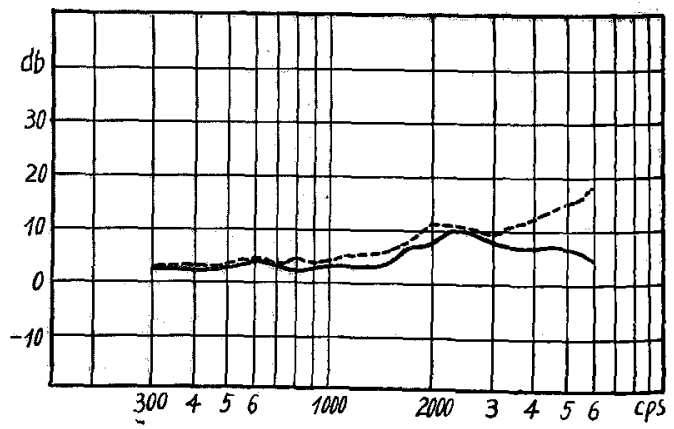




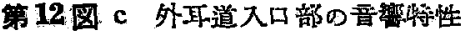
音源正面 と侧面の音圧筀

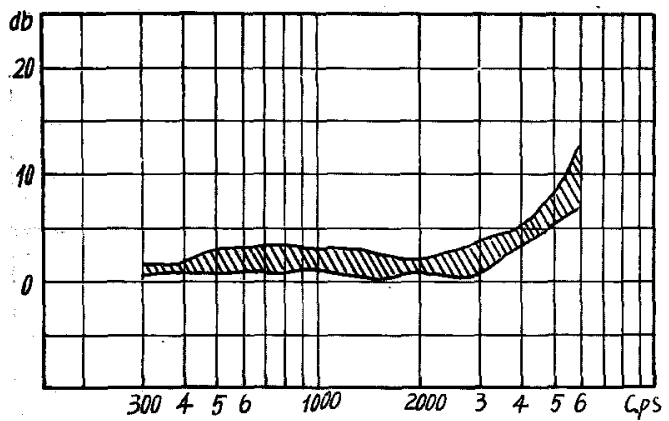

割線は音源が側面にある場合の特性曲線である。

曲線の形状は大体類似していて，側面の方が正面の場 合より各周波数に沶いて音压が良くなつている。この両 者の音王差を現わしたものが第 12 図 cである。

音源が正面及び側面の場合，低音域で虫両者共感度は 悪く，3000cps 以下では側面が 1 万至 $5 \mathrm{db}$ 感度が良く なつているが 4000cps では 3 乃至 $5 \mathrm{db}, 5000 \mathrm{cps}$ では 5 乃至 $8 \mathrm{db}, 6000 \mathrm{cps}$ では 7 万至 $13 \mathrm{db}$ と側面の音圧は 正面の音圧より良くなつている。

雨者の曲線は大体平行をなしていて，共に $1000 \mathrm{cps}$ 以上から濑次 $2000 \mathrm{cps}$ 迄増大し，それから以上はかな り平行な形状を示めしているから、これ等の作用は耳就 の影響と考觉られる。

\section{v. 外耳道入口部の音王と聴力の関係}

i) 測定方法

音源より $50 \mathrm{~cm}$ の位置に頍部を括学，前記第9図の 置を用いて probe tube microphone の先端を外耳 道入口部の中心に位置させて音仕を測定し，外耳道入口 の音压が，各周波数について常に $60 \mathrm{db}$ level（絶体音 圧単位)になるように音源の強さを調節固定し，音源の 減衰抵抗を增加して，最小可聴閔值を求め，60db level より最小可聴閶值までの減衰抵抗值を各周波数について 求めた。

ii) 测定結果

嘼部及び耳款の音蠁作用を除名して，外耳道入口部に 同一音壬があたえられた場合の聴力はいかなる音響特性 があるかを測定した・この埸合の聴力は，外耳道の音響 特性と，鼓膜から内耳をでの音㗽特性の綜合された耳の 感度恃性である・この特性曲線は上にあがるほど感度が 良い事を意味し，周波数間の感度差は曲線の高さの差に よって decibel により知る事ができる。
その代表的な4例を示したのが第 13 図 1，2，3，4で ある.この 4 例を比較すると，著しい相異があるが。一 般に低音域の感度は悪く，第 13 図 1 の如く $500 \mathrm{cps}$ 以 上から $5000 \mathrm{cpc}$ まで耳の感度特性が平坦を埸合と，第 13 図4の如く600cps から整時高音になるにつれて， 感度が悪くなつている例があり，第 13 図 3 の如く 900 cps から $1000 \mathrm{cps}$ の間で急激に感度が良くなつている 例があり，第 13 図 2 の如く $500 \mathrm{cps}$ より高音になるに つれて，感度が良くなり，3000cps で明瞭な「ビーク」 を作つているものもある。

第 13 図 5 はこれ等の曲線の 周波数に刘して最大なる

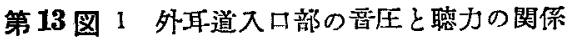

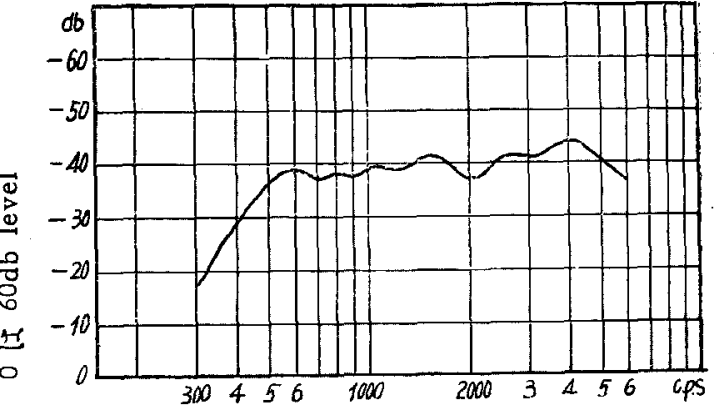

第 13 図 2 外恥道入口部の望圧 聴力の関保

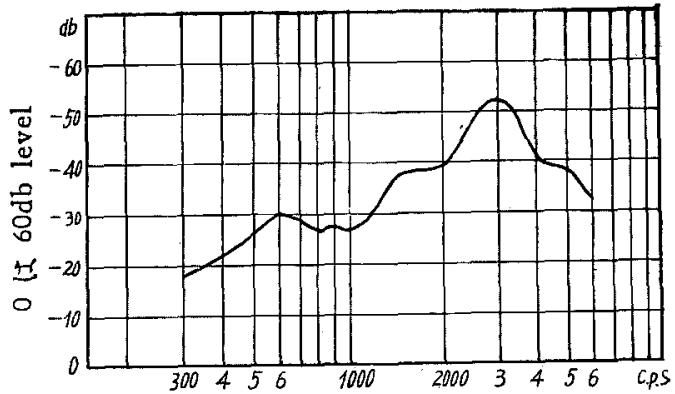

第 13 図 3 外恥道入口部の豆压と聴䚮の関保

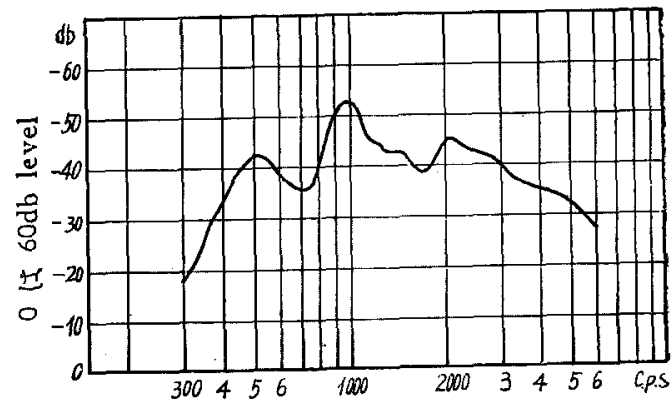


第 13 図 4 外耳道入听部の音压々聴力の関保

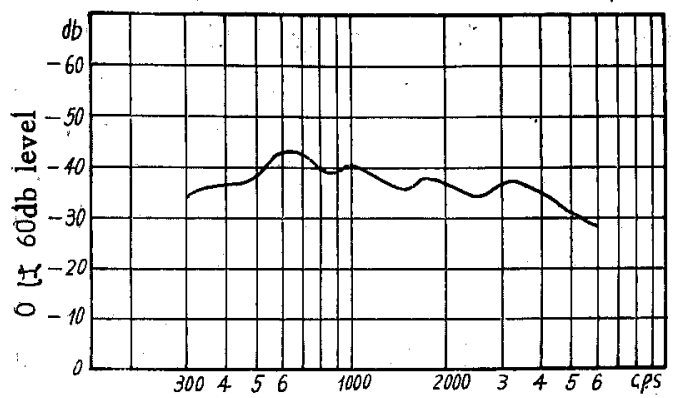

第 13 図 5 外耳道入口部の意圧と聴力の関保 被検者 10 例の感度差

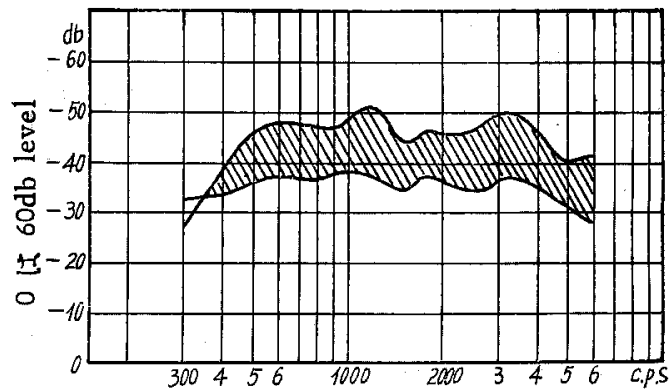

点をつらね，更に最小なる点をつらね，その個人による 感度美を図示したものである・これによると $400 \mathrm{cps}$ は $5 \mathrm{db}, 500 \mathrm{cps}$ は $10 \mathrm{db}, 1000 \mathrm{cps}$ は $10 \mathrm{db}, 2000 \mathrm{cps}$ は $10 \mathrm{db}, 3000 \mathrm{cps}$ は $12 \mathrm{db} 4000 \mathrm{cps}$ は $12 \mathrm{db}, 5000 \mathrm{cps}$ は $10 \mathrm{db}$ の差があって，これは正常耳間の個人の感度差で ある。

VI. 外耳道の音響特性

耳の感度周波数狩性と考える場合，先す外耳道の共鳴 郊果を考学なければならない，外耳道は先れを通つて内 方偣波の伝導が起るのであるが，一端を開口せる共鳴 器と考学る事ができる。この意味で外耳道の音響特性を 知る事悱常に興味ある研究である。

著者は鼓营前面音压を測定し，これと開放音場音圧及 び外耳道入口部音王を比較し，外耳道の音響周波数特性 を測定した。

（A）外耳道入口部音王之鼓臊前面の音圧

i）測定方法

前記第 9 図の装置を使用して外耳道入口の音圧を Probe tube microphone 飞て测定し，次臌膜前面に外 耳道を通して probe tube microphone の先端を挿入 して音圧を測定する・この両者の音圧比を測定した綃果 は第14図である。

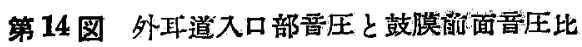
代琵列 3 例

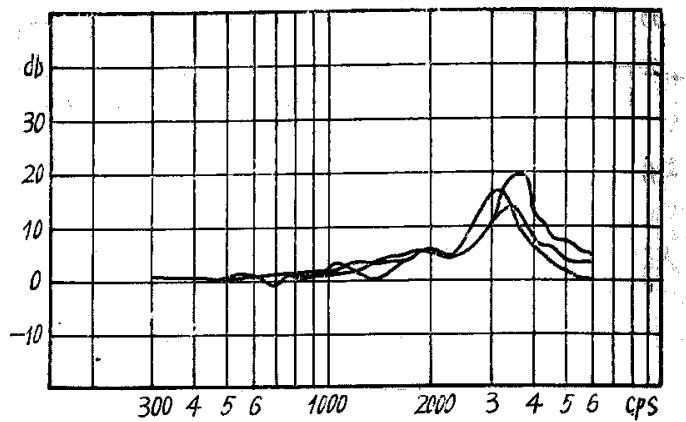

ii) 测定結果

㖕膜前面の音圧は外耳道入口部音圧に比して $1000 \mathrm{cps}$ 以上より潮次増加し，2500 cps より $3800 \mathrm{cps}$ の間に 15 $\mathrm{db}$ より $20 \mathrm{db}$ の「ピーク」が諗められる。この「ど整 ク」け然耳道共鳴によるるのである。

すでに 1947 年に Winner and D.A. Ross によって 測定され，その外耳道共鳴ピークは第8図の如く 12 耳 の平均值に执いて 4000 cps に13db の「ピーク」があ り，個人差が殆んどないと述べているが，著者の湘定し は被檢者によつては $2500 \mathrm{cps}$ から 3800eps の間に下と 一ク」があり，からその「ビーク」は 15dbより $20 \mathrm{db}$ に亘つてかなりの個人羑が認められる。

橭膜前面音圧対外耳道入口部音王比の周波数特性曲線 は，頭部に対する音源の方向が，どのように変化しても 変化しない：この性質より鼓膜前面対外耳道入口部音王 比の周波数特性曲線は，外耳道の共鳴による事を裏がき している.

（B）．䛠膜前面音圧と開放音場音圧

i) 测定方洗

測定回路は第 9 図に示す如く「スピーカー」を音源と し，鼓膜前面に A と同様に probe tube microphone の先端を㨂入して音圧を測定し，次に開放音場音圧を湘 定するときは probe tube microphone の位置はその まつにし，被検者のみその位置より去らしめて湘定す る.

各周波数についてこの而測定值の差を求める.このよ らにした 各周波数汸いての 测定值が第 14 図の曲線て ある．音源は頭部正面の場合と側面の場合とについて澌 定した.

ii) 湘定結果

鼓膜前面の 音圧曲線は 音源の 方向によつて 異なり第 
第 15 图鼓膜前面吾圧 開放吾埸吾圧比 実線江音源正面 割線吉晋源側面の場合

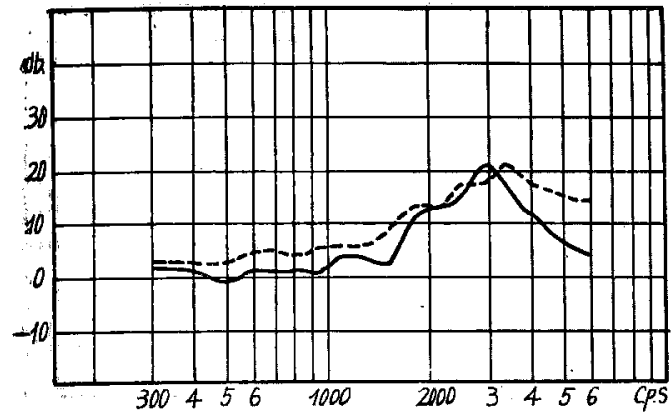

15 図の実線は音源が 頭部正面の場合の特性曲線で，割 楾は同一耳の音源方向が側面の場合の特性曲線である。 実線之割線とは音源の方向によって曲線の形状がかわつ ている. 即ら音源が正面と側面では特性曲線の最大「ピ ーク」の位置る少し変化を受けているばかりでなく，側 面は $3000 \mathrm{cps}$ 以上の高音域の 音圧が増加し $10 \mathrm{db}$ にむ 達している.これは明らかに頭部及び耳款の音波に対す る迴折・反射及び耳款の集音作用の音波方向による変化 と考えられる。

鼓膜前面の音圧を $\mathrm{P}_{\mathrm{T}}$ ，開放音場音纴を $\mathrm{P}_{\mathbf{O}}$ 外耳道入 口部音圧を $\mathrm{P}_{\mathrm{E}}$ ととすれば

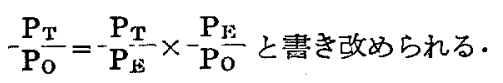

但し $-\mathrm{P}_{\mathbf{T}} \mathrm{P}_{\boldsymbol{E}}$ は鼓膜前面と外耳道入口部の音圧比でその 特性曲線は，すでにりのAに述べた第13 図である。

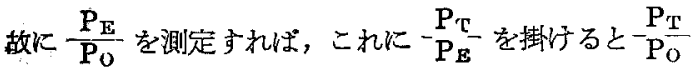
が得られる事になる。

$\mathrm{P}_{\mathrm{E}} \mathrm{P}_{\mathrm{o}}$ の測定が被検者 10 名について得られた代表例は 第 12 図の如くで音源の方向によって変化している.

鼓膜前面と音場音王との比, 即ら $-\frac{P_{\mathrm{T}}}{\mathrm{P}_{\mathrm{O}}}$ の曲線は音源 の位置が前面と 側面によって 相異しているのは第 15 図 の如くであるが，この例の $\frac{\mathrm{P}_{\mathrm{T}}}{\mathrm{P}_{\mathrm{E}}}$ は前述の如く音源の方 向によつてその曲線は変化しないから音源前面の ${ }^{-} \mathrm{P}_{\mathrm{T}}$ の曲線に, 音源前面の $-\mathrm{P}_{\mathrm{y}}$ の曲線を足すと, 音源前面 の $\frac{\mathrm{Pr}_{\mathrm{r}}}{\mathrm{P}_{\mathrm{o}}}$ 即ち鼓膜前面と開放音場音仕比の曲線が得られ る.この関倸を示めしたものが第16戝である。

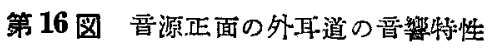

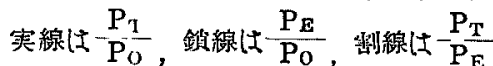

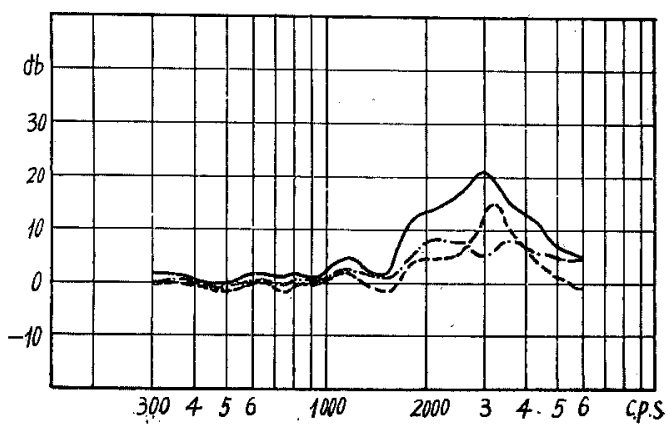

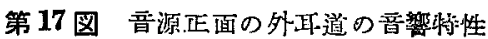

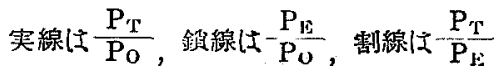

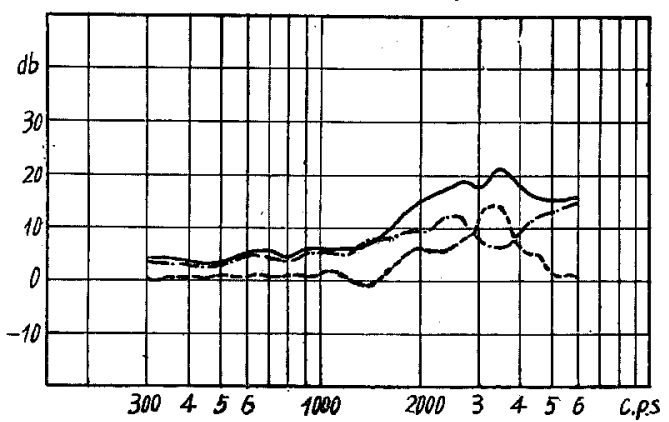

前記の $\frac{\mathbf{P}_{\mathbf{T}}}{\mathbf{P}_{\mathrm{k}}}$ に音源側面の $\frac{\mathrm{P}_{\mathbf{E}}}{\mathrm{P}_{\mathrm{O}}}$ を加えれば音源側面の $\frac{\mathrm{P}_{\mathrm{T}}}{\mathrm{P}_{\mathrm{O}}}$ が求められる・この曲線が第 17 図である.

第 16 図艾び第 17 図の実線は第 15 図の例の害線之割 線に相当する・故に鼓膜前面の音圧と外耳道入口の音圧 の比の周波数特性曲線 $\frac{\mathrm{P}_{\mathrm{T}}}{\mathrm{P}_{\mathrm{I}}}$ は被梌者の耳に個有なるの で音源の方向によつても变化せず，な括音埸が完全な free field であろらが,なからうが,これによっても变 化を受けない特徽がある。

VII. 外耳道入口部と同じ音王を受話器にて 発生せしめた場合の聴力

i) 测定方法

第9 図の装置中「スピーカー」を除き，受話器に代光， 更に受話器に probe tube microphone 第 18 図の如 〈插入し，受話器を耳にあて〉生ずる外耳道内音圧を $60 \mathrm{db}$ level に調節固定し, 受話器の音圧を減衰抵抗器 によつて 60db level より最少可德閾值迄低下せしぬた 
場合の減衰抵抗の值を各周波数について測定し，更に第 19 図の如く受話器に 6cc coupler を接続して標準コン デンサーーィクにて $60 \mathrm{db}$ の音任を各周波数について発 生せしぬそそぞれの $60 \mathrm{db}$ lenel 上り閾值に達する运 の減衰抵抗值を测定した・Vで湘定した結果とこの二方 法による测定值との同一被検者に対する比萮は第 20 図 である。

第 18 図受話器に probe tube microphone 点插入しけ所

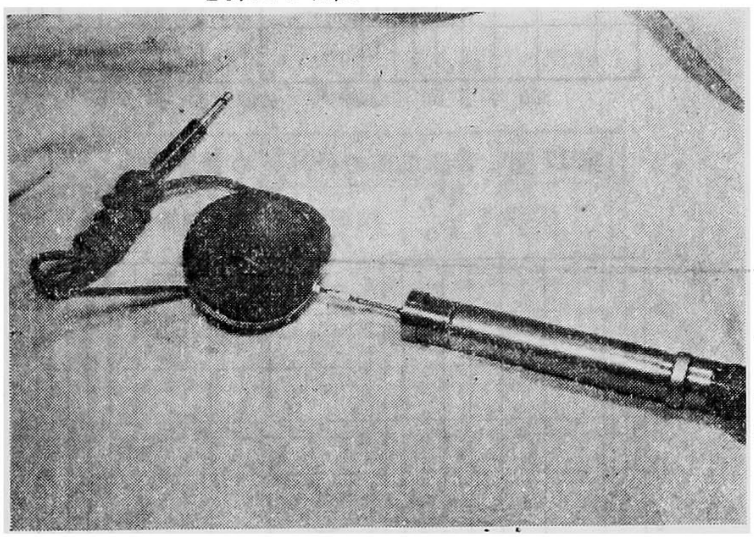

第 19 図 受衙器を 6cc coupler に接続した所

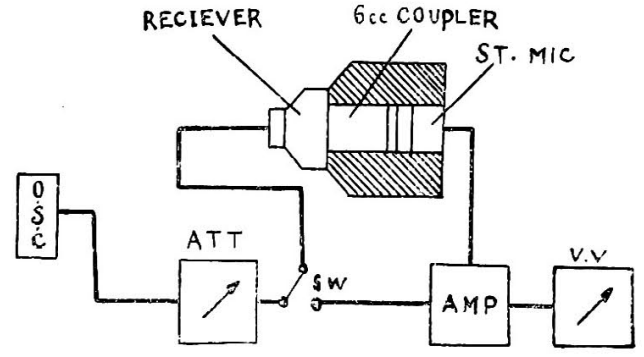

第 20 图 a. 项感要周波数特性 实線仕 probe tube 法, 䠖線けカプ フー

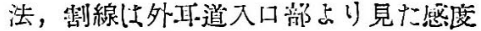

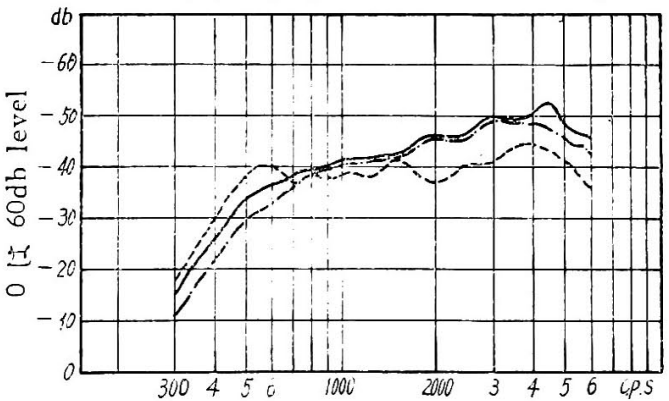

第 20 図 b. 耳.の感変周波数特性

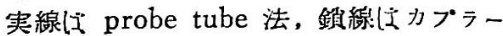
法，割線に外耳道入口部より見た感度

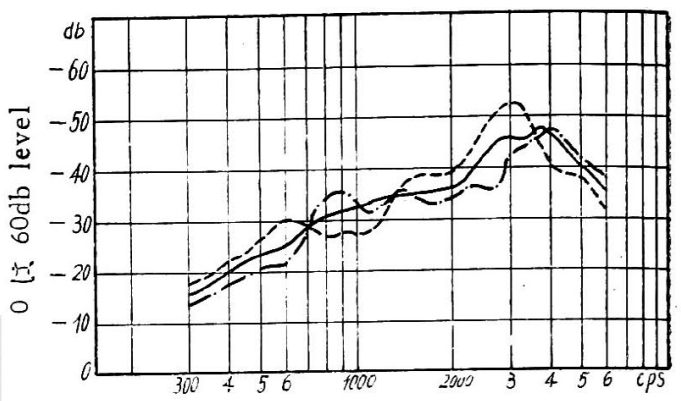

第 20 図 c. 牙の感脣周波数特性 実線は probe tube 法，錤線はカプラー 法，割線け外耳道入口部々り見た感度

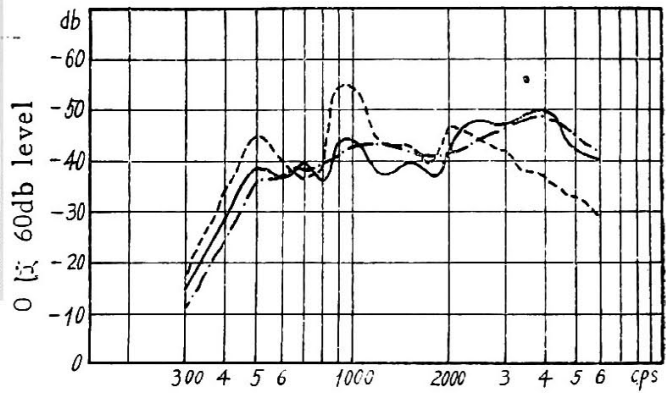

第 20 図 d. 耳-の惑度周波数特性 実線は probe tube 法, 頳線げカプラー 法，制線は外斥道入日部より見た缶限

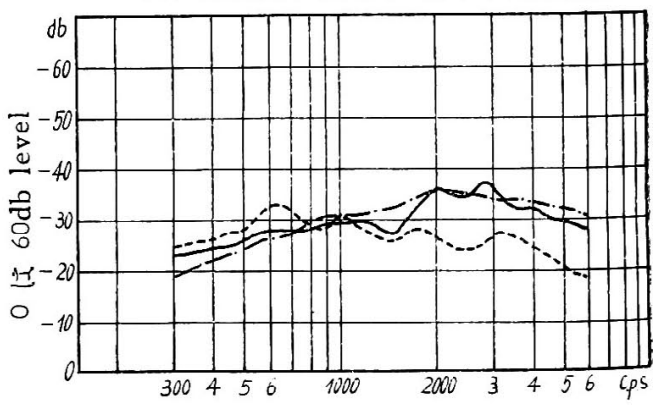

ii）測定結果

第 20 図の割線は開放音場における外耳道入口より見 た耳の感度周波数特性の測定值であり，矢線及び鎖線は 受話器についての感度周波数特性の測定値である. 但し 笑線は probe tube 法による感度周波数特性，鎖線は カプラー法によるものである。

被検者についてそれぞれの測定結果の内の代表例を選 
んだのが第 20 図の a,b, c, dである.a, b, c 3曲線の形 状恬大体類似していて，低音域の感度は 300 cps 比して 500eps の聴力は第 20 図 a 及び c の如く 25db 位急堌す

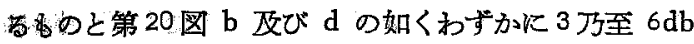
位の堌加にとどまるものとがある。 500cps から 5000 cps までの感度曲線恃水平に走り，4000cps を越えると 曲線性緩るやか心下降し，感度がや入低下乙始めるのが 認ぬられる・割線実線及び鎖線共に各例を通じて，大体 平行しているが，実袙及び鎖線の感度は $1000 \mathrm{cps}$ 以下 で好割線より劣るが，1000 cps 以上では契線及び 鎖䠌 の感度の方が良くなつている.第20図 c の如く，割線 及び実線共に $900 \mathrm{cps}$ より $1000 \mathrm{cps}$ にかけて感度曲線に や」急激な変化が認められる例がある。これは鼓膜かあ るいは耳小骨連鎖の共鳴が特に著しい例之考えられる。

開放音場で然耳道入口より測定した耳感度と受話器 そよって测定された感度との間は $1000 \mathrm{cps}$ を中心とし て低音域では前者の感度が 2 乃至 $5 \mathrm{db}$ 勝り，高音域で 恃後者が 6 乃至 $14 \mathrm{db}$ 勝っていることは同一被検者で 湘定器の音圧を補正し一致させて子测定条件が違うと聴 カは同じ值が得られない事を示している。

実線と、鎖線は受話器による 聴力測定であり probe tube microphone で外耳道内の音圧を $60 \mathrm{db}$ に調節固 定して剆定する方が実際に受話器が耳にあたえる音圧が 測定されているが，6cc coupler にて音圧を測定し，そ れを耳にあてた場合は coupler では受話器と coupler の間に空気のもれる事がないが, 受話器を耳にあてた場 合はすきがあつて音代があれるから coupler で測つ た音纴よりは異つた音圧を耳にあたえる危険がある・そ れが象線と鎖線との decibel 差によって 示めされてい る. 本実験儿使用した藤木䡛受話器はこの点良好である ために実線之鎖線の差は殆んど認められず，600cps 以 下の低音域においての差は，受話器と耳の間の leak に よるるのである・しかしこの受話器では coupler 更正 でも実用価値があるが著者の経験ではこの間の差が多く て 10db K達する受話器もあつた。

\section{VIII. 総 括}

耳の機能を知るためにはその音響に対する感度特性を 知らねばならない，解剖構造がどのようになつていて る。たと充ば鬼と人間の耼解剖的に異つていてもこの 二つの耳㹸つての感度特性が同一ならば, 耳の機能は 同一とみなせる・

この見地からすれば，耳の機能に関しては感度周波数 特性を測定する事が重要である。この方面の研究は緒言
中の交献的考察に述へた如く，頭部，耳瑴，外耳道の音 響的機能に 関しても研究は少なく, 测定ブーターも少 くこれ等の機能について明白な成果が得られてない。 なおどれが頭部の 音響的機能か，どれが外耳道の機能 か，両者の関連についても明確では無い．碩部及び外耳 道の音響的機能が明嘫でないのに德力検查は「オージオ メーターー」の受話器によつて湘定されている.これによ つて得られる「デーがー」が，我そが自然の状態で得ら れている聴力といかなる関係が炀るか，明白にして置か ねばならない.このような見地から probe tube microphone によって種になる測定条件下に頍部，耳款及び 外耳道の音響测定を行つた。

頭部自身が聴力に及忹す影響价いては，Tröger, Sivian-white 及文び Steinberg の测定があるが，前2 者 と後者の 测定条件は異っていて正確に比較できないが Steinberg の测定值は音源が一側面から反対側に廻つた 場合の一耳の聴力变化であるから音源が正面から左及び 右にまわつた場合の影響の和と考光られる・この值を2 で割れば音源が前面より一側面にまわつた場合の聴力の 变化に相当するから，この值と Tröger の測定值とを 比較するとかなりの相異がある・Steinberg の実験の 測定条件が明磪をかいているので，著者は開放音場に和 いて，音源の強さ絶体音圧 $60 \mathrm{db}$ level に固定した 300 cps より 6000 cps の純音で, 音源を幁部前面と側面に廻 して，頭部及び外耳道の差異を測定した・その結果は第 11 図で音源の方向による聴力の変化についての 個人差 は比較的少い。この点は頭部の直径と波長の比が，個人 的にあまり差がない事より当然考えられる・音源が正面 の場合は，外耳道に入る音波は頍部に上る延折及び耳款 の集音作用によるものであるが，音源が側面にある場合 は頭部の反射に上る音俚増加と取款の集音作用が加わつ たものであるが，音源が前面と側面との恥力の相異は主 と乙て頭部の反射作用による音波のせき止め音圧增加加 耳款に集められて外耳道に入ると考えられる。

頍周に対して波長が長い場合は音波は主として廻折す るが，幁周に較べて波長の短い高音は，幁部表面で反射 され，その表面では音圧が増加する。

幁周と波長比に閏する頭部の前面と側面と後面とにつ いての音圧比が表の如く計算されている．預周に対して 波長比 0.5 亿相当する音波の振動数は $256 \mathrm{cps}$ で比 1.0 は $512 \mathrm{cps}$ 比 2.0 は $1024 \mathrm{cps}$ に相当し Ray leigh の音 源前面及び側面の音王を decible に換算すれば $256 \mathrm{cps}$ では前面と側面の音压比は $0 \mathrm{db}$ で $512 \mathrm{cps}$ では $6 \mathrm{db}$, 
表 頭周と波長比についての音圧比 (Ray leighによる)

\begin{tabular}{|l|l|l|l|}
\hline 0 & 20 & 10 & 05 \\
\hline 面 & 0.69 & 0.50 & 0.29 \\
\hline 面 & 032 & 0.28 & 0.26 \\
\hline & 0.36 & 0.24 & 0.23 \\
\hline
\end{tabular}

$1024 \mathrm{cps}$ では $6 \mathrm{db}$ で著者の测定值 $300 \mathrm{cps}$ で0乃至 2 $\mathrm{db}, 500 \mathrm{cps}$ では 2 万至 $3 \mathrm{db}, 1000 \mathrm{cps}$ では 2 万至 $6 \mathrm{db}$ に較べるとかなり良く一致している。

前記の Trögel の测定値は第 5 図より計算すれば，前 面と側面の 音圧比は $200 \mathrm{cps}$ では $0 \mathrm{db} 500 \mathrm{cps}$ では側 面が $1 \mathrm{db}$ 良く，2500cps では $1 \mathrm{db} ， 5000 \mathrm{cps}$ では 0.5 $\mathrm{db}$ それぞれ側面が良くなつている。

Sivian and White では $1000 \mathrm{cps}$ が 6db, 5000cps は $5 \mathrm{db}$ 良好となつている・

これに反して Steinberg の测定值は音源が右側より 左側に迴つた埸合の右耳の聴力变化であるから，音源が 前面から右及び左側に迴つた場合の聴力变化の和亡考兄 られる・故に Sleinberg の测定值を2で割れば，著者 の測定值と此較できる. 彼の測定値は $500 \mathrm{cps}$ で $3.5 \mathrm{db}$, $1000 \mathrm{cps}$ で $4 \mathrm{db}, 2050 \mathrm{cps}$ で $4 \mathrm{db}, 3000 \mathrm{cps}$ で $5 \mathrm{db}$, $4000 \mathrm{cps}$ で $8 \mathrm{db}, 5000 \mathrm{cps}$ で $12 \mathrm{db}$ で, 第 11 図の著者 の測定值と大体類似している：

以上の成績は頭部の音波に対する影響を，聴力を標集 として測定した成綘であるから，これは被検者の感覚に 上る測定である・故に他覚的测測定するために，音源が 所部前面と側面にある埸合の外耳道入口の音王の相異を 測定したのが第 12 図である・これにより自覚的と他覚 的測定の間に比例的傾向が認められる。他覚的測定は正 確であるが，聴力を規準として測定した場合は同一被検 者によつても時間的間値の変動が数 decibel あるから 両者の測定は完全に一致する事はない。しかしこの点を 考慮すれば，屾者の測定はほぶ一致しているとみなされ る.

願部の影響は $4000 \mathrm{cps}$ から著明に現れて来るのが認 められる。

更にもとに戻つて第 12 図の音源正面と側面之の音圧 特性には 4000 cps 以下忪が無いがこれ等の曲線その ものは 1000 cps 以上加ら漸次 $2000 \mathrm{cps}$ 迄增大し，それ から以上はかなり平行な形状を示していて第 12 図 Cの 曲線よりはかなり高いからこ犳等の作用は主として耳款
の集音作用によるものであるう：

前述の如く頭部による聴力への影響が認められたから 頭部の影琿を除去した聴力を測定しなければならない。 この測定値は第 13 図である. 第 13 図の聴力感度特性性 外耳道から中耳及び内耳の感度特性が綜合されたもので ある.故にこれ等の振動系には個人差があると考光られ るから第 13 図の 4 例の感度特性が 種ふなる变化を示め すのは当然であ万ち．ことに第 13 図3の如く $1000 \mathrm{cps}$ の「ピーク」は耳小骨連鎖, あるいは鼓膜の共鳴による ものが特に著明に現れたるのと解釈すれば非常に興味が ある. 正常耳の間にある聴力の感度差が第 13 図 5 k示 めされているが，これが外耳道及び中耳の音響堌幅機能

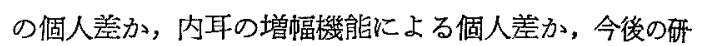
究にまたねぱならない。

第 13 図の感度特性に外耳道がどの程度影響するが 見るために祭耳道の音響特性を測定した。外耳道の共嗅 については Winner and Ross は第8図に示めした如 く12 名についての平均值であるが，個人差も殆んとな いといっている・しかし著者の测定では第 14 図の如く 「ピーク」のある位置にる個人差があり，4000 cps に「ピ 一タ」のある例は成人では認められない，高さむ15か ら $20 \mathrm{db}$ にあり, Winner and Ross $の 13 \mathrm{db}$ と蛙. なり相異している。

前記の第 13 図の感度特性から，第 14 図の外耳道の增 幅特性を引くと，鼓膜から内耳迄の感度特性となる，外 耳道の增幅特性は $1500 \mathrm{cps}$ 迄は殆んぞ平坦であるから， 前記の第 13 図 3 の $1000 \mathrm{cps}$ の「ピーク」は内耳の感度

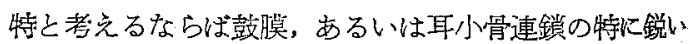
共鳴が加かつた感度周波数特性上考えられる。

第 16 図及び第 17 図の成續より外耳道の音響特性愔 源と耳の方向とが，どの位置にあっても変化されない が，外耳道入口部の音響特性愔源に対する耳の方向伅 よって変化される故に，外耳道入口部の音圧を一定の音 压 level に調節固定して聴力を測定すれば外耳道の音響 特性は，被検者それそれれに固定されているし，それ以下 の中耳及び内耳も個人によつてそれぞれ一定であるから 被検者の耳の感度周波数特性に対しては，外耳道入口部 の音圧 level より測定する「り」で述べた方法が，むつ とも安定した条件に和ける合理的な测定洼である事がわ かる.これと普通の聴力検榃に用いられている受話器作 よる耳の感度特性测定法を第 20 図の如く比較する事に よつて，後者は萦の耳の感度を得るものではなくて，あ る人工的条件のるとに和惊る感度周波数特性であり， 
$100 \mathrm{cps}$ 以上では約6乃至 $14 \mathrm{db}$ の誤盖を生じている。 但 L受話器で測定した正常耳の感度周波数特性を基準之 して病耳の感度特性を測り雨者の間の羑をるつて病耳の 聴力損失とする従来の「オージオメトリー」は不合理で はないが, しかし受話器によって耳の感度周波数特性を 測定する事は真の意味の 感度特性ではない事が，第20 因の比較により証明する事ができる。

受話器と free field で得られる聴力間に美異のある ことを測定している者に Sivian and White や Munson その他がある. 彼等の測定結果は第 21 园である.
その感度の図示形式は図の下部程耳の感度が良好である ことを示し著者の形式と反対であるが，彼度の成績では free field の畾力と受話器洼の恥力を比較すれば，即ら a 曲線 (free fleld)と b 曲線 (受話器) 問は 2000 cps 以 上で約 $10 \mathrm{db}$ の開きがあり，前者が後者より良好とな つている・この関係は著者の剆定法によるものでは第 20 図の如く同一耳について䒠楾と鑜線に 比して割線は $2000 \mathrm{cps}$ 头上で約 $10 \mathrm{db}$ の開きがあり，開放普場の聴 力か逆に低下している・これは测定法の相違に基因する ものである.

第21 図 感度周波数特性 Sivian and White 及び Munson による

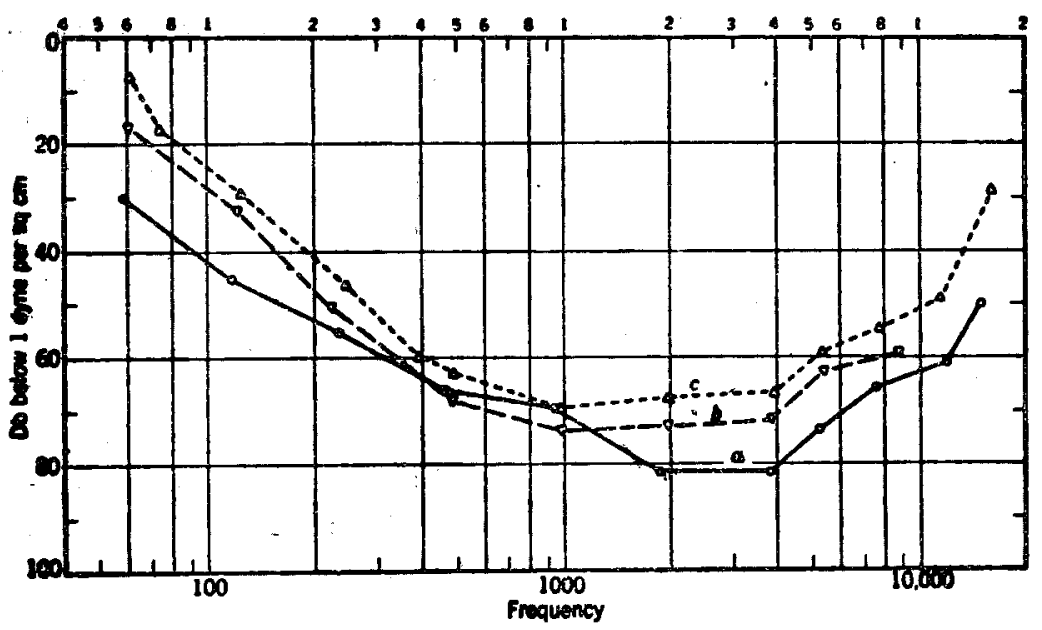

彼等の湘定は無反響堂で 充分な free field の条件を 満足されている音場で測定した成儥であるとしても頭部 及び耳㲄の 影響を受けた 聴力曲線であり，著者の第 11 図の1〜5の曲線に相当する・この場合は著者の曲線で も $2000 \mathrm{cps}$ 以上は曲線が上昇し Sivian and White 及び Munson の測定にかなりよく一致している・但し 著者の使用した音場は無反響室でなから室內の反射も あつて彼等の成績とは詳しくは一致しないであろらが， Winner and Ross の無反隌窒内での鼓膜前面の音圧と 音場音压との比の曲線と著者の同曲線は形に扎いて, 類 似しているから著者の使用した音埸る無反響坴の条件と 著しく異つているとは考えられない。

受話器による德力と音場による聴力を比較する場合， 後者では Sivian and White の湘定においても音源の 方向によって聴力は変化するから，両者の聴力を㛜密に 比較することは不合理である。

これに反して外耳道入口の音生より聴力を测定する晈
合には音源の音波が周囲の壁からどのように反射され， どのような音場が形成されていてもな和音源の位置がど の方向であつても常に同じ成績が得られる.

この特徽よりして，本法によつて得られる聴力を基準 として，他の条件に括ける聴力を比較することが合理的 である・

更に本法は単なる防音室で行らことができて無反锌室 を必要としない点にも実施容易な長所を有していると云 える。

以上の如く頭部本び耳豰，然耳道が耳の感度特性に及 ほす寸作用を実测より解明し，耳の感度周波数特性のもつ とる合理的な測定洼は「V」の測定法である・但しこの

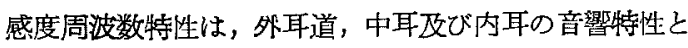
聴神経の感度周波数特性より合成されれている・

\section{IX. 結 論}

i）開放音場の 音圧を一定の「レベル」に固定して， 音源と頍部の 方向による聴力変化を測定する事によつ 
て，䫚部（耳豰を含む）の音響特性を自賞的方法で求め $\pi$.

ii）音埸音仕と你耳道入口部音圧との比が 音源の方 抲によって变化する状態を測定し(i) の自覚的方注に上 つて得られる成績と比較し，その間にかなり良い一致が 認められた。

iii）開放音場の音压が鼓膜面上K及洔す周波数特性 の測定と，多耳道入口部之鼓膜面上の音圧比を測定し， 両者を比較する事によつて外耳道の音響特性を得た。外 耳道の音響特性は音源に対する耳の方向によつて変化し ない事笑を認めた。

iv）（iii）の事実より外耳道入口部の音圧レベルを各 周波数について一定にし，これより耳の感度特性を得る 方法を発見し，これがもつとも合理的な耳の感度周波数 特性測定法である事を認めた・故にこれが耳の感度特性 《対する標準となるべき方泆と思的れる。

v) 前項(iv)の方法と従来の受話器を用いて得られる 耳の感度特性とを比較して，その両者の間に $1000 \mathrm{cps}$ 上上は6 万至 $14 \mathrm{db}$ に及ぶ相異がある事を認奴た。故に この相異から受話器によつて得られる耳の感度特性は $1000 \mathrm{cps}$ 以上では補正されなければならない。

\section{主 要 文 献}

1) Rayleigh: Theory of Sound Vol 2. and Phil. mag, 13, 1907. 2) Bachhous: Handbuch der Physik 1927. 3) Ballantine S.: Physical Review 32: 988, 1928. 4) Tröger, J.: Physikalisch Zeitschrift 26:31, $1930 . \quad$ 5) Langenbeck, $B .:$ Pflügers Archiev für die gesamte Physiologie 266: 11, 1931. 6) Bèkèsy G.V.: Annalen der physik 14: 51, 1932. 7) Fletcher, H. and Munson, W.A.: J. Ácoust. Soc. Amer. 4: 82 108, 1933. 8) Sivian, L.J. and White S.D.: J. acoust Soc. Amer. 4: 288 321, 1933.9 9) Steinberg, J.C. and Snow, W.B.: Bell System Technical Journal $13: 245,1934$. 10) Müller, J. Blach and Dunn:

J. Acoust.. Soc. America 10: 6, 1936.

Barany, E: Acta Otolaryngologica vol. 26, 1938.
13) Winner, F.M. and Ross, D.A.: J. Acaust. Soc. Amer. $18 \mathrm{Na} 2$ 401, 1946. 14) Romanow, F.F.:

J. acoust Soc. Amer. 14: 294 304, 1942. Meyer, E.: Handbuch der Physik Bd8. Akustik. 16) Wever, E.G.: Psychol. Bull., 36: 143 $\sim 187$, 1939. P.L. Harriman's Twentieth century psych. 371 386, 1946. 17) Martin, D.W. and Anderson L.J.: J. acoust. Sac. Amer. 19: 63 70, 1947. 18) Wener, E.G. and Laurence, M.: Ann. of Otol. Rhinol. Laxyngol, 1950. 19) De Vries, H.: Acta. Oto-laryngol., 36, 230 235, 1948. 20) Davis, $H$. and Stebens, S.S.: Hearing 1948. 21) Danil W.M. and Martin, L.T.A J. acoust. Soc. Amer. $22: 6,1950 . \quad$ 22) Fletcher, H.: (1) Speech and Hearing incommunication 1953. (2) J. Acoust. Soc. Amer. 24 : 129 131, 1952. 23) Corliss, E.L.R. and Eurkhard, M.D.: J. Acoust. Soc, Ameri 25: 990 993, 1953. 24) Albrite, J.P. and Shutts, R.E.: Sixth International Congress of Otol. p.p. $126 \sim 128,1957 . \quad 25)$ Major James P.A, Edwin, S., Maurice B.W.: Richard K.C, Edith L.C, and Mahlon D.B. Arch. of Otol. 1958. 26) 恩地豊： J. Acoust. Soc. Amer. 21. 404 410, 1949.

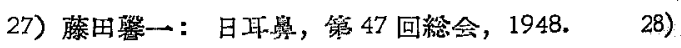

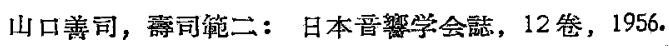

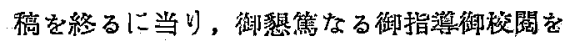
睗わつた恩師堀口舟作教授，恩地豊教授に深甚 なる謝意を㥭げると共に，佂せて種々に御指㾞 を戴いた森山学兄並びに教室員の諸兄に厚く感 謝します。

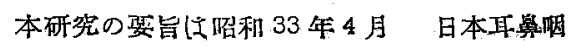
啹科学会籍 59 回総会並びに昭和 32 年 11 月才 ージオロギー学会におかて発蒜した。

（原稿到着＝哈稩 34.5 .6 日一急載） 